\title{
O pomenu predmetnih oznak in podatka o afiliaciji v raziskovalnih knjižnicah v COBISS.SI: praksa izpolnjevanja polj bloka 6XX in podpolja 70X8
}

\author{
On the importance of subject cataloguing and information about author \\ afiliation in research libraries in COBISS.SI: the practice of indexing fields 6XX \\ and subfield $70 \times 8$
}

\section{Maja Peteh ${ }^{1}$, Primož Južnič}

IZVLEČEK: Prispevek prinaša nov vpogled v katalogizacijsko prakso v sistemu COBISS.SI, posebej z vidika potreb bibliografskih podatkov za vodenje bibliografij raziskovalcev in raziskovalnih organizacij. $\mathrm{V}$ prispevku sta evalvirani dve vsebini katalogizacijske prakse, ki sta neobvezni, a priporočljivi. Raziskava se ukvarja z ugotavljanjem doslednosti vnosa podatka v podpolje 70X8 in analizo obstoječih možnosti za uporabo tega podatka pri pripravi bibliografij raziskovalne organizacije. Uporabljeni so trije metodološki pristopi: a) izvedba in analiza spletnega vprašalnika za knjižničarje $(n=113)$, zaposlene $v$ visokošolskih in specialnih knjižnicah, o njihovem delu, b) analiza izpolnjevanja podpolja 70X8 (afiliacija avtorja) $v$ bibliografskih zapisih, kreiranih za potrebe bibliografij raziskovalcev $v$ sedemdesetih raziskovalnih knjižnicah, ki sodelujejo $v$ sistemu COBISS.SI, in c) analiza beležk podatkov o kreiranih bibliografskih zapisih $(n=401)$ desetih knjižničarjev bibliografov. Ugotavlja se nedoslednost predmetnega označevanja bibliografskih zapisov in vnosa podatka o zaposlitvi avtorja. Vnos podatka o zaposlitvi avtorja naj bi bil obvezen za zapise, ki jih želi določena ustanova uvrstiti v bibliografijo ustanove, a ga redno vnaša le $1 \%$ knjižničarjev bibliografov, nikoli pa ga ne vnaša $16 \%$ knjižničarjev bibliografov. Predmetne oznake v slovenskem jeziku dosledno vnaša $83 \%$ anketiranih knjižničarjev bibliografov, le $26 \%$ pa jih vnaša tudi v drugem jeziku. Knjižničarji bibliografi povprečno vnesejo 4,5 predmetne oznake $v$ slovenščini in eno $v$ tujem jeziku. Pogosteje vnašajo nekontrolirane predmetne oznake. Zaradi posebnosti slovenskega knjižničnega sistema, ki povezuje vzajemni katalog in informacijski sistem o raziskovalni dejavnosti (SICRIS), so rezultati uporabni v slovenskem kontekstu in okoljih COBISS. Predmetne oznake v tujem, predvsem angleškem jeziku so dodana vrednost zapisu tudi zaradi vse večjih izmenjav podatkov med COBISS.SI ter vzpostavljenim Nacionalnim portalom odprte znanosti in drugimi zbirkami. Vnos predmetnih oznak sicer ni obvezen, vendar pa gre za pomemben podatek. Kljub temu ni zanemarljiv delež knjižničarjev bibliografov, ki se ne zavedajo pomena tega podatka ali pa ga ne vnašajo zaradi preobremenitve.

KLJUČNE BESEDE: bibliografije raziskovalcev, bibliografije ustanov, COBISS.SI, SICRIS, znanstvene knjižnice, bibliografski podatki, vsebinska obdelava, knjižničarji bibliografi

\footnotetext{
${ }^{1}$ Korespondenčni avtor: mag. Maja Peteh, Univerza v Ljubljani, Biotehniška fakulteta, Oddelek za gozdarstvo in obnovljive gozdne vire, in Gozdarski inštitut Slovenije, Ljubljana, Slovenija, maja.peteh@gozdis.si.

${ }^{2}$ Dr. Primož Južnič, Univerza v Ljubljani, Filozofska fakulteta, Oddelek za bibliotekarstvo, informacijsko znanost in knjigarstvo, Ljubljana, Slovenija, primoz.juznic@ff.uni-lj.si.
} 
ABSTRACT: The paper gives a new insight into the cataloguing practice in the COBISS.SI system, primarily regarding the necessity of bibliographic data for the management of bibliographies for researchers and research organisations. The paper evaluates two areas in the cataloguing practice, both of them optional but recommended. The research deals with the consistency of the entry of author affiliation and with the analysis of the existing possibilities of using it in the process of preparing bibliographies for research organisations. Three methodological approaches are used: a) performance and analysis of an online questionnaire for academic and special librarians $(n=113)$ about their work as librarians bibliographers, b) analysis of indexing subfield 70X8 (author affiliation) in bibliographic records, created for the needs of researchers' bibliographies, in seventy libraries participating in the COBISS.SI system, and c) analysis of the data logs of 401 records created by ten librarians bibliographers. The results show the inconsistency of subject indexing of bibliographic records and of the entry of the author affiliation. The entry of this information should be mandatory for the records that an institution wishes to be included in its bibliography but only $1 \%$ of librarians bibliographers regularly enter this information, whereas $16 \%$ of librarians bibliographers never enter it; $83 \%$ of the librarians bibliographers who answered the questionnaire consistently enter subject headings in Slovenian, only $26 \%$ also in other languages. On average they enter between 4.5 subject headings in Slovenian and one in another language. They tend to index uncontrolled subject headings more often. Due to the special nature of the Slovenian library system, which links the shared catalogue and the current research information system (SICRIS), the results are only applicable in the Slovenian context and in the COBISS environment. Subject headings in a foreign language, especially in English, represent an added value to the record because of the increasing data exchange between COBISS.SI and the established portal Open Science Slovenia and other databases. Even though the entry of subject headings is optional, the data is very important. However, the proportion of librarians bibliographers who are not aware of the importance of this information or do not enter it due to work overload is not negligible.

KEYWORDS: bibliographies of researchers, bibliographies of institutions, COBISS.SI, SICRIS, research libraries, bibliographic data, subject cataloguing, librarians bibliographers

\section{Uvod}

Posebnost slovenskega knjižničnega sistema je sistem COBISS z vzajemnim katalogom COBIB.SI, ki je povezan tudi z informacijskim sistemom o raziskovalni dejavnosti (Current Research Information System - SICRIS). Ta vključuje podatkovne zbirke o slovenskih raziskovalcih in raziskovalnih organizacijah ( $v$ nadaljnjem besedilu: $\mathrm{RO}$ ) ter njihovi dejavnosti (Južnič, 2015; Peteh in Južnič, 2018). Povezanost teh dveh sistemov nam ponuja vrsto možnosti za izpise bibliografij raziskovalcev in RO ter posledično evalvacijo njihovega prispevka v znanstveni produkciji. Vodenje bibliografij ni vezano na izgradnjo kataloga (fizične) knjižnične zbirke, saj se v sistem vnašajo tudi dela, ki jih knjižnica nima v svoji zbirki; dela so lahko objavljena na spletu ali celo neobjavljena. Knjižničar bibliograf jih običajno vnaša $v$ sistem za zaposlene $v$ matični ustanovi knjižnice, lahko pa tudi kot storitev za zunanje naročnike. Delo več kot tretjine knjižničarjev bibliografov ni vezano na referalno delo z uporabniki in na pripravo letnih poročil, dve tretjini pa tudi ne na pripravo bibliografij (Peteh in Južnič, 2018).

Pri tem delu ima zagotavljanje kakovosti pomembno vlogo, saj podatki pomembno vplivajo na storitve, namenjene raziskovalcem, kot so izpisi osebnih bibliografij, prijave na razpise Agencije za raziskovalno dejavnost Republike Slovenije (ARRS), bibliografski kazalci uspešnosti za izvolitev v nazive $v$ okviru univerz ipd. (Dornik et al., 2017). Zato je pomembno stalno 
spremljanje kakovosti in postavljanje kazalnikov kakovosti v katalogizaciji (Dornik, 2019). Za vsebinsko pravilno razvrstitev skrbijo Osrednji specializirani informacijski centri (OSIC).

Knjižničarji so vedno bolj pomembni tudi kot partnerji pri znanstvenoraziskovalnem delu. V slovenskem okolju so nepogrešljivi $v$ procesu evalvacije, saj skrbno beležijo informacije o objavah raziskovalcev svoje organizacije $v$ sistem COBISS.SI. Sistem COBISS.SI je povezan s sistemom SICRIS in omogoča vpogled $\mathrm{v}$ bibliografije raziskovalcev ter tudi vrednotenje njihovega dela, in sicer po metodologiji, ki jo določa ARRS. Hkrati so ti podatki uporabni tudi kot vir za različne bibliometrijske raziskave (Južnič, 2015). Objave raziskovalnih rezultatov, pri katerih slovenski raziskovalci uporabljajo te podatke, so pogosto opažene in tudi ustrezno citirane.

V okviru slovenskega Nacionalnega portala odprte znanosti so vzpostavljeni repozitoriji vseh slovenskih univerz (DKUM - Digitalna knjižnica Univerze v Mariboru, RUL - Repozitorij Univerze v Ljubljani, RUP - Repozitorij Univerze na Primorskem, RUNG - Repozitorij Univerze v Novi Gorici), repozitorij raziskovalnih organizacij (DiRROS - Digitalni repozitorij raziskovalnih organizacij Slovenije) ter samostojnih visokošolskih in višješolskih izobraževalnih organizacij (ReVIS - Repozitorij samostojnih visokošolskih in višješolskih izobraževalnih organizacij). Repozitoriji so kompatibilni z navodili portala OpenAIRE in vključeni v različne spletne imenike, agregatorje ter iskalnike (npr. OpenDOAR, ROAR, BASE). Tako izpolnjujejo zahtevo pokrovitelja, Evropske komisije, ki le prek portala repozitorijev, kompatibilnih z navodili portala OpenAIRE, preverja izpolnjevanje določil iz pogodbe o sofinanciranju. Pomembno je izpostaviti, da so vzpostavljene povezave med repozitoriji in sistemom COBISS.SI, kar zelo olajša delo knjižničarjev. Ti so dopolnili seznam opravil v okviru znanstvenoraziskovalnega dela $z$ urednikovanjem vnosov $v$ digitalnih repozitorijih (Peteh in Južnič, 2018). Kvaliteten bibliografski zapis v sistemu COBISS predstavlja tudi osnovo metapodatkov za prenose $v$ druge sisteme (Koler-Povh, 2016), tudi institucionalne e-repozitorije. Vzpostavljena je namreč možnost prenosa bibliografskih podatkov iz sistema COBISS v prej naštete repozitorije. $V$ tem procesu ni vzpostavljena kvaliteta kakovosti, razvijalci sistema predpostavljajo kvaliteto zapisov v COBIB.SI. Če bibliografski zapis ne vsebuje določenih podatkov, se ti ne morejo prenesti.

Knjižničar katalogizator se mora zavedati, da z vnosom zapisov v sistem COBISS.SI:

- sodeluje pri izgradnji vzajemnega kataloga,

- sodeluje pri gradnji nacionalne bibliografije,

- zapisi postanejo predmet izmenjav podatkov med COBISS.SI in vzpostavljenim Nacionalnim portalom odprte znanosti. Bibliografski zapisi so namenjeni tudi mednarodni izmenjavi z WorldCat (OCLC), normativni zapisi se izvažajo v VIAF (Virtual International Authority File), uporabniki pa jih lahko izvažajo tudi v orodja za upravljanje referenc in citiranje. Pravilni podatki v zapisih so zato zelo pomembni in kažejo na pomembnost dela knjižničarjev katalogizatorjev.

\section{Bibliografija raziskovalne organizacije}

$\mathrm{V}$ tem prispevku se ukvarjamo z bibliografijo RO, ki lahko vključuje znanstveno, strokovno, poljudno in umetniško produkcijo zaposlenih (običajno raziskovalcev), pa tudi prispevke, ki govorijo o organizaciji. Škerget in Rifl (2014) pišeta, da je »sestavljanje Slovenske bibliografije naloga NUK, za bibliografije slovenskih raziskovalcev sta odgovorna Institut informacijskih 
znanosti v Mariboru - IZUM ( $\mathrm{z}$ izobraževanjem ter z upravljanjem in vzdrževanjem baze SICRIS) in Javna agencija za raziskovalno dejavnost Republike Slovenije (ARRS)." Sistem COBISS in zbirka SICRIS se $v$ slovenskem raziskovalnem prostoru uporabljata za izpise bibliografij (raziskovalcev). Menimo, da so $v$ tem kontekstu za kvaliteten izpis bibliografije organizacije najbolj odgovorni knjižničarji bibliografi. Ti $v$ postopku katalogizacije izvedejo izbor, vrednotenje, vsebinsko analizo, klasifikacijo. Postopek je opisoval že Logar (1970) in je še vedno temelj dela bibliografa, spremenil se je le medij, $s$ katerim bibliograf ureja zbirko in medij objave. Bibliografija je, kot pravi Mišković (2010), 'končni izdelek' in hkrati 'praksa'.

Informacijski sistem SICRIS se uporablja za potrebe evalvacije raziskovalcev, raziskovalnih skupin in organizacij. Omogoča različne izpise, npr. 'Vrednotenje bibliografskih kazalcev raziskovalne uspešnosti po metodologiji ARRS'. Izpis je mogoče pripraviti a) za nabor raziskovalcev, ki so trenutno vključeni $v$ RO, b) z izbiro 'Vrednotenje skupine izbranih raziskovalcev', kjer so že zajeti raziskovalci, trenutno vključeni v RO, dodati pa je možno tudi druge raziskovalce in c) z opcijo 'Vrednotenje skupine izbranih raziskovalcev', kjer sami definiramo, katere raziskovalce želimo vključiti. Vse omenjene izpise lahko pripravimo za poljubno obdobje, kar pa predstavlja zagato. Algoritem izpisa namreč ne upošteva možnosti, da raziskovalec ni bil del $\mathrm{RO}$ celotno obdobje ali celotno koledarsko leto in v izpis vključi objave raziskovalca, ki jih je ta pripravil v sklopu dela v drugi RO. Dodatno pa ne upošteva možnosti, da objave izhajajo z zamikom - tudi večletnim (npr. članki, ki izidejo po zaključku dela raziskovalca $v$ RO). Izpisi tipa 'Vrednotenje bibliografskih kazalcev' so tako namenjeni vpogledu $\checkmark$ trenutni raziskovalni potencial $\mathrm{RO}$.

Ta problem so zaznali tudi predstavniki OSIC-ev in na ARRS, kjer ugotavljajo, da »če izpišemo vrednotenje raziskovalne uspešnosti določene organizacije za izbrano obdobje, npr. 20132017, v izpis ne zajamemo podatkov o objavah tistih raziskovalcev, ki npr. od leta 2016 niso več zaposleni na fakulteti, hkrati pa so $v$ izpis zajeta dela raziskovalcev, ki so $v$ organizaciji zaposleni na novo. SICRIS (Current Research Information System) je namreč sistem, ki kaže trenutno stanje, ne pa retrospektivnega. Če bi želeli pri organizacijah izpis del glede na kriterij vnesene šifre ustanove (podpolje 70X8), je trenutno edina možnost izpis bibliografije ustanove (BIB261) v COBISS3/Izpisi. «Zaključujejo s sklepom o vključitvi možnosti izpisa bibliografije ustanove tudi glede na podatke v podpolju $70 X 8$ (Zapisnik ..., 2018).

ARRS poseduje podatke, kdaj je bil raziskovalec dodan $v$ RO ali bil iz nje brisan, a žal tudi ti podatki ne držijo - preprosto zato, ker RO in vodje raziskovalnih skupin ne (po)skrbijo za ažurnost podatkov; upošteva se namreč datum, ko je RO ta podatek/spremembo sporočila.

Iz sistema COBISS (prek COBISS+ z iskalno predpono FC ali z vmesnikom COBISS3) lahko pripravimo izpis bibliografije ustanove na podlagi izpolnjenega podpolja 70X8, kamor se vnaša podatek o pripadnosti avtorja instituciji, t.i. šifro ustanove/organizacije. Podpolje je namenjeno vodenju bibliografij ustanov $v$ sistemih COBISS in naj bi bilo obvezno v zapisih, $\mathrm{ki}$ jih želi določena ustanova uvrstiti v bibliografijo ustanove (COMARC/B format, 2019) in kjer se uporablja šifrant ustanov/organizacij. Popolnost izpisa bibliografije ustanove je tako odvisna od prepoznane potrebe posameznih knjižničarjev bibliografov.

\section{Pomen vsebinske obdelave pri vnosu zapisov za vodenje bibliografij}

V sistemu COBISS so predmetne oznake (vnašamo jih v polja 600-610) in klasifikacijske oznake (vnašamo jih $v$ polja 675-686) pomembne $z$ vidika najdenja gradiva $v$ katalogu. Vzajemni 
katalog predvideva enoten način obdelave, torej predpostavlja uporabo »istih načel, pravilnikov in standardov" (Likar, 2003). Vnos predmetnih in klasifikacijskih oznak je priporočljiv, izjema je obvezno podpolje 675c (klasifikacijski UDK vrstilec z enotnim šifrantom) (COMARC/B format, 2019). Vsebinska analiza je odvisna od končnih uporabnikov, tipa knjižnice, knjižnične zbirke, katalogizatorjem pa so na voljo posamezni sistemi in geslovniki. Kot je ugotavljal že Klemen (2011), sta katalogizatorjem na razpolago Spletni splošni slovenski geslovnik (SSSG) in spletna Univerzalna decimalna klasifikacija (UDCMRF12), ki pa še nista učinkovito povezana s sistemom za vzajemno katalogizacijo.

Za potrebe izvajanja analiz kakovosti podatkov v bibliografskih zapisih so v IZUM-u oblikovali nabor dimenzij za ugotavljanje kakovosti podatkov $v$ bibliografskih in normativnih zapisih. Kakovostni podatki so navedeni $v$ edinstvenem zapisu, semantično točni, točno prepisani, strukturalno in vsebinsko popolni, strukturalno in vsebinsko skladni, oblikovno dosledni, predvideni oz. neodvečni, aktualni, lahko pa so tudi dodatno informativni (Badovinac, 2018).

Celostnih analiz za blok $6 \mathrm{~s}$ tega vidika še ni na voljo, v rezultatih spremljanja kakovosti v IZUMu pa zasledimo, da v približno $10 \%$ bibliografskih zapisov manjka podatek vsaj v enem od polj 600-610 (ti podatki zagotavljajo dodatno informativnost zapisa), medtem ko je zatipkanih podatkov v poljih 600-610 razmeroma malo (Badovinac, 2019).

V novih mednarodnih katalogizacijskih načelih (Galeffi et al., 2019), ki pri nas še niso prešla v prakso, ima predmetna oznaka večjo vrednost in postane bistvena točka dostopa ('točka dostopa za predmetne oznake'). Predmetne oznake bodo tako enako pomembne kot normativna točka dostopa (avtor oz. avtorji, stvarni naslov, datum izida oz. izhajanja, standardne številke, identifikatorji in 'ključni naslovi' opisovane entitete).

Pri svojem delu se mora knjižničar katalogizator zavedati, da je zapis kakovosten, če so vanj vneseni vsi podatki, potrebni za identifikacijo publikacije, in če je $v$ zapis vgrajenih dovolj podatkov, ki uporabniku omogočajo, da zapis najde. V Sloveniji se tako istočasno, vzajemno gradita vzajemni katalog in nacionalna bibliografija, zapisi pa so tudi predmet izmenjav podatkov med COBISS.SI ter vzpostavljenim Nacionalnim portalom odprte znanosti in drugimi zbirkami.

Predmetno označevanje zapisa od knjižničarja bibliografa zahteva poglobitev $v$ vsebino dela $v$ obdelavi, kar v procesu izdelave bibliografskega zapisa zahteva dodaten čas in poglobljeno poznavanje področja. Zaradi drugih delovnih obremenitev (Peteh in Južnič, 2018) smo v tem delu raziskave predpostavljali, da knjižničarji bibliografi prihranijo nekaj delovnega časa na račun vključevanja predmetnih oznak.

\section{Metodologija}

V raziskavi nas je zanimala doslednost vključevanja predmetnih oznak (polja 600-610), klasifikacijskih oznak (polja 675-686) in podatka o afiliaciji (podpolje 70X8) v bibliografske zapise v bazi podatkov COBIB.SI, ki so predmet bibliografije raziskovalcev. Predpostavljali smo, da knjižničarji bibliografi pogosteje vključujejo predmetne oznake $v$ slovenskem jeziku kot $v$ angleškem in da če so $v$ delu navedene ključne besede le $v$ angleškem jeziku, jih večinoma ne prevajajo.

Po izvedbi pilotnega vprašalnika v letu 2016 smo vnos v izpopolnjeni e-vprašalnik omogočili od 18. januarja do 21. februarja 2017. Vprašalnik je bil pripravljen z orodjem 1KA, obvestilo pa 
je bilo z e-pošto posredovano prek vseh dostopnih obveščevalnih strokovnih list (strokovna knjižničarska društva, seznami NUK, liste sekcij ZBDS) in prek skupin na Facebooku. V letu 2017 je bilo $v$ slovenskih visokošolskih in specialnih knjižnicah zaposlenih 554 delavcev za knjižničarsko delo (redno zaposleni in delavci, ki niso redno zaposleni) (BibSist, 2018), rezultati prikazujejo prakso $20 \%$ teh delavcev. $V$ tem času je bilo v slovenskih knjižnicah aktivnih 652 knjižničarjev katalogizatorjev (Dovoljenja za vzajemno katalogizacijo, 2018). Točnega podatka, koliko se jih ukvarja z vodenjem bibliografij, ni.

Vprašalnik je vseboval 19 vprašanj, od tega dve demografski vprašanji. Vprašalnik je odprlo 213 respondentov, od tega je bilo 113 vprašalnikov izpolnjenih $v$ celoti ali vsaj delno zadovoljivo. Rezultati prikazujejo izkušnje in prakso $20 \%$ vseh strokovnih delavcev, zaposlenih $v$ visokošolskih in specialnih knjižnicah. Analiza časovnega vidika kreiranja zapisov v sistemu COBISS3 je prikazana v članku Peteh in Južnič (2018). V tem prispevku se osredotočamo le na rezultate naslednjih dveh anketnih vprašanj:

- Kako pogosto $v$ katalog vnašate predmetne oznake $v$ slovenskem jeziku in drugih jezikih (blok 6)?

- Kako pogosto izpolnjujete podpolje 70X8 (šifra ustanove/organizacije)?

$\checkmark$ pilotni izvedbi ankete je sodelovalo 50 knjižničarjev. $V$ podporo anketnemu vprašalniku smo 10 knjižničarjev bibliografov pridobili tudi za sodelovanje $v$ drugem delu naše raziskave. Ta je obsegal beleženje podatkov o zapisih, kreiranih v izbranem obdobju. Knjižničarje bibliografe smo prosili, naj si v času od 20. januarja do 20. februarja 2017 izberejo 10 zaporednih dni in v tem času v vnaprej pripravljeno preglednico beležijo podatke o kreiranih zapisih. Sodelujoči so tako imeli možnost, da sami poiščejo obdobje, ko bodo njihove delovne obveznosti zajemale (tudi) katalogizacijo, ko ne bodo preobremenjeni z drugimi delovnimi obveznostmi in ko bodo prisotni na delovnem mestu.

V preglednici beleženja podatkov o kreiranih zapisih so bibliografi beležili 12 vrst podatkov. To so:

- skupen čas kreiranja zapisa,

- efektiven čas kreiranja zapisa,

- motnje pri delu (brez motenj, telefon, uporabnik, sodelavec, sestanek, drugo),

- tip dela,

- maska zapisa,

- podatek, ali gre za e-dostopen vir,

- zahtevnost vnosa (subjektivna ocena: zelo zahteven, srednje zahteven, nezahteven),

- način začetka izdelave zapisa (nov zapis, prevzem iz kataloga WorldCat, prevzem iz baz ISSN ali COBISS.net, uporaba predloge, priredi v nov zapis, prevzem zapisa ali prevzet zapis s popravki),

- jezik in pisava gradiva (slovenski jezik, tuj jezik, ki ga vsaj delno obvlada, tuj jezik, ki ga ne obvlada),

- vsebinska obdelava (skupno število izpolnjenih podpolj v poljih 600-610, od tega število podpolj 610a v slovenščini in drugih jezikih),

- vsebinska oprema vira (ključne besede in UDK-vrstilec so navedeni na viru, ključne besede je podal avtor ali jih bodo določili sodelavci, zadolženi za vsebinsko obdelavo gradiva in klasifikacijo), 
- urejanje normativnih imen avtorjev v bazi CONOR.SI (število izpolnjenih polj avtorstva (70X) in od tega število kreiranih ali dopolnjenih normativnih zapisov in število izpolnjenih polj korporativnega avtorstva (71X).

Naštete podatke smo pridobili za 401 bibliografski zapis. Dodatno je vseh 10 sodelujočih posredovalo tudi informacije o vrsti knjižnice (visokošolska ali specialna), v kateri so zaposleni, in letu, ko so pridobili dovoljenje za vzajemno katalogizacijo. $V$ tem članku prikazujemo le rezultate, vezane na izpolnjevanje polj bloka 6 in podpolja 70X8.

V tretjem sklopu smo se odločili sami preveriti doslednost izpolnjevanja podpolja 70X8. To smo izvedli s križnim preverjanjem izpisov iz baze podatkov COBIB.SI in iz sistema SICRIS. V raziskavo smo zajeli le izpise $\mathrm{RO}$, ki imajo lastno knjižnico in so imele $v$ času pridobivanja podatkov (junij 2016) več kot 20 raziskovalcev, kar je razvidno iz sistema SICRIS. Predpostavljamo, da so potrebe po knjižničnih storitvah $v$ teh organizacijah dovolj visoke, da je organizacija prepoznala potrebo po organizaciji knjižnice tudi s tem, da ima zaposlenega svojega knjižničarja bibliografa, ki skrbi za bibliografijo raziskovalcev in celotne ustanove. Zajeli smo podatke 26 specialnih knjižnic oz. samostojnih inštitutov in 44 visokošolskih knjižnic oz. fakultetnih ustanov (skupaj 70). Iz baze podatkov COBIB.SI smo pridobili izpis zapisov z izpolnjenim podpoljem o tipologiji in afiliaciji avtorja, pri čemer je zadostovalo, da je ta podatek zabeležen pri vsaj enemu od avtorjev. Predpostavljali smo, da je knjižničar bibliograf podatek o afiliaciji dopolnil pri vseh ali nobenem izmed avtorjev svoje ustanove. Iskanje smo omejili na obdobje 2010-2015. Iskalna zahteva je vsebovala naslednji iskalni niz: 'PY=2010:2015 AND FC=[šifriran podatek, "šifra ustanove/organizacije», v sistemu COBISS]* AND (TD=1* OR TD=2* OR TD=3*)'. Iz izpisa smo zabeležili podatek o številu zadetkov.

Za izbranih 70 raziskovalnih organizacij smo nato pripravili primerjalni izpis bibliografije $\mathbf{v}$ sistemu SICRIS z metodo 'Vrednotenje bibliografskih kazalcev raziskovalne uspešnosti po metodologiji ARRS', in sicer $v$ obdobju 2010-2015. V tem primeru podatek v podpolju 70X8 ne vpliva na izpis podatkov, saj algoritem zajame zapise, če je raziskovalec $v$ trenutku priprave izpisa vključen v RO. Na osnovi izpisa smo zabeležili podatek o skupnem številu vključenih del.

\section{Rezultati}

\subsection{Vključevanje predmetnih oznak v bibliografski zapis}

Na vprašanje o doslednosti predmetnega označevanja bibliografskih zapisov je odgovorilo 82 od 113 sodelujočih $v$ raziskavi. Kar $84 \%$ sodelujočih knjižničarjev v bibliografske zapise za objavljena dela dosledno vnese predmetne oznake $v$ slovenskem jeziku. Od tega $1 \%$ predmetnega označevanja opravijo sodelavci, saj imajo $v$ knjižnici bibliografski opis ločen od vsebinske obdelave. Med sodelujočimi knjižničarji bibliografi jih $4 \%$ navede predmetne oznake le, če ima vir ključno dokumentacijsko informacijo, kjer so navedene tudi ključne besede, ali pa podatke za vsebinsko obdelavo posreduje avtor, 9 \% knjižničarjev bibliografov pa bibliografske zapise le občasno opremi s predmetnimi oznakami (tabela 1).

Predmetne oznake $v$ angleškem jeziku dosledno vnaša 26 \% vprašanih knjižničarjev, 24 \% jih navede le, če so navedeni na viru ali jih posreduje avtor, $37 \%$ pa občasno. Delež knjižničarjev bibliografov, ki nikoli ne vnašajo predmetnih oznak v angleščini, je 13 \% (tabela 1). 
Tabela 1: Vnos predmetnih oznak v polja 600-610 v slovenskem jeziku in drugih jezikih $(n=82)$

\begin{tabular}{lllll}
\hline Vnos predmetnih oznak & \multicolumn{3}{l}{ Slovenski jezik } & \multicolumn{2}{l}{ Drugi jeziki } \\
\cline { 2 - 5 } & $\begin{array}{l}\text { Frekvenca } \\
(\mathrm{n})\end{array}$ & $\begin{array}{l}\text { Delež } \\
(\%)\end{array}$ & $\begin{array}{l}\text { Frekvenca } \\
(\mathrm{n})\end{array}$ & $\begin{array}{l}\text { Delež } \\
(\%)\end{array}$ \\
\hline Dosledno vnašam & 61 & $\mathbf{7 4}$ & 21 & $\mathbf{2 6}$ \\
\hline Določam le objavljenim delom (tip 1* in 2*) & 7 & 9 & 0 & 0 \\
\hline Občasno vnašam & 9 & 11 & 30 & 37 \\
\hline Če so navedene v delu ali jih posreduje avtor & 3 & 4 & 20 & 24 \\
\hline Nikoli & 1 & 1 & 11 & 13 \\
\hline Vnaša sodelavec, zadolžen za vsebinsko obdelavo & 1 & 1 & 0 & 0 \\
\hline Skupaj & $\mathbf{8 2}$ & $\mathbf{1 0 0}$ & $\mathbf{8 2}$ & $\mathbf{1 0 0}$ \\
\hline
\end{tabular}

Tabela 2 prikazuje rezultate beleženja podatkov o kreiranih zapisih in prikazuje podatek, kdo je določil predmetne oznake. Največkrat je knjižničar bibliograf tisti, ki zapisu določi predmetne oznake $(48,4 \%)$. $\vee 26,2 \%$ je predmetne oznake posredoval avtor ob oddaji dela za vnos v osebno bibliografijo, v $24,9 \%$ pa so bile ključne besede navedene na viru.

Tabeli 1 in 2 skladno dokazujeta, da knjižničar bibliograf v visokošolskih in specialnih knjižnicah kreira celoten zapis in vsebinska obdelava večinoma ni ločena od katalogizacije.

Tabela 2: Vir predmetnih oznak v poljih 600-610 $(n=401)$

\begin{tabular}{lllll}
\hline Vrsta gradiva (tip) & $\begin{array}{l}\text { Število } \\
\text { zapisov } \\
\text { (n) }\end{array}$ & $\begin{array}{l}\text { Na viru } \\
\text { (\%) }\end{array}$ & $\begin{array}{l}\text { Določi } \\
\text { avtor } \\
\text { (\%) }\end{array}$ & $\begin{array}{l}\text { Določi } \\
\text { bibliograf } \\
\text { (\%) }\end{array}$ \\
\hline Znanstveni članki (1.01-1.03) & 23 & 47,8 & 43,5 & 8,7 \\
\hline Strokovni in poljudni članki (1.04-1.05) & 66 & 7,6 & 40,9 & 51,5 \\
\hline Prispevki v kongresnih zbornikih (1.06-1.13) & 28 & 53,6 & 32,1 & 14,3 \\
\hline Poglavja v monografijah (1.16-1.17) & 8 & 12,5 & 0,0 & 62,5 \\
\hline Drugi prispevki v serijskih publikacijah (1.19-1.25) & 46 & 4,3 & 8,7 & 87,0 \\
\hline Poročila, elaborati ipd. (2.12-2.15) & 75 & 4,0 & 20,0 & 76,0 \\
\hline Zaključna dela (2.08-2.11) & 58 & 46,6 & 27,6 & 25,8 \\
\hline Kongresni zborniki (2.3* in 2.25) & 15 & 13,3 & 13,3 & 73,4 \\
\hline Druge monografije (2.01-2.07, 2.16-2.24) & 19 & 21,1 & 15,8 & 63,1 \\
\hline Neobjavljena dela (3*) & 63 & 47,6 & 30,2 & 22,2 \\
\hline Povprečje (\%) & $/$ & $\mathbf{2 4 , 9}$ & $\mathbf{2 6 , 2}$ & $\mathbf{4 8 , 4}$ \\
\hline
\end{tabular}

${ }^{1}$ Dodatno je v 25,0 \% zapisov predmetne oznake določil sodelavec, ki je zadolžen za vsebinsko obdelavo in ni bibliograf.

Pregled tabel s podatki o kreiranem 401 bibliografskem zapisu desetih knjižničarjev bibliografov pokaže, da je $396(98,9 \%)$ zapisov opremljenih s predmetnimi oznakami. V polja 600-610 so povprečno vnesli 6,7 predmetne oznake, od tega večino $(78,4 \%)$ v polje 610 , ki je namenjeno prostemu oblikovanju predmetnih oznak. $V$ polje 610 vnesejo povprečno 4,7 predmetne oznake, $v$ drugih jezikih pa 1,4 predmetne oznake. Priporočila avtorjem člankov $v$ znanstvenih revijah in navodila študentom pri oblikovanju zaključnih del običajno navajajo 35 ključnih besed. $V$ primeru angleških revij je ta zahteva omejena na ključne besede (keywords) $v$ angleščini, $v$ primeru del $v$ drugih jezikih (npr. slovenščini) pa navajajmo ključne besede $v$ jeziku publikacije in enako število ključnih besed $v$ angleščini. Podroben pregled po tipologijah 
zapisov kaže močno izstopanje zapisov za znanstvene članke. Tu je povprečje predmetnih oznak v drugih jezikih 4,5, kar pripisujemo visokemu deležu opremljenosti člankov s ključnimi besedami. To povprečje je v skladu s priporočili avtorjem. Tudi sicer iz povprečja o številu izpolnjenih podpolj v poljih 600-610 izstopajo gradiva, kjer je vsebina pogosteje že opremljena s ključnimi besedami (tabela 3 ).

Če iz analize izvzamemo dela s tipologijo $3^{*}$ (neobjavljena in izvedena dela), ugotovimo, da je med 401 zapisom 252 (74,6 \%) zapisov za dela v slovenščini. Pri zapisih za dela v slovenskem jeziku ( $n=252)$ jih je $249(98,8 \%)$ opremljenih $z$ vsaj eno predmetno oznako v slovenskem jeziku in $34(13,5 \%)$ tudi $z$ vsaj eno predmetno oznako v drugem jeziku. Pri zapisih $(n=86)$ za dela, napisana $v$ drugih jezikih, jih je 71 ( $82,6 \%$ ) opremljenih z vsaj eno predmetno oznako $v$ slovenskem jeziku in $40(46,5 \%)$ z vsaj eno predmetno oznako v drugem jeziku.

Tabela 3: Predmetne oznake v poljih 600-610 v slovenščini in v drugih jezikih ( $n=82)$

\begin{tabular}{lllll}
\hline Vrsta gradiva (tip) & $\begin{array}{l}\text { Povprečno } \\
\text { število } \\
\text { vseh } \\
\text { podpolj } \\
\text { 600-610 }\end{array}$ & $\begin{array}{l}\text { Delež } \\
\text { podpolj } \\
\mathbf{6 1 0 a} \\
\text { (\%) }\end{array}$ & $\begin{array}{l}\text { Povprečno } \\
\text { število } \\
\text { podpolj } \\
\mathbf{6 1 0 a} \text { v } \\
\text { slovenščini }\end{array}$ & $\begin{array}{l}\text { Povprečno } \\
\text { število } \\
\text { podpolj } \\
\mathbf{6 1 0 a} \text { v } \\
\text { drugih } \\
\text { jezikih }\end{array}$ \\
\hline Znanstveni članki (1.01-1.03) & 9,6 & 81,0 & 4,6 & 4,5 \\
\hline Strokovni in poljudni članki (1.04-1.05) & 5,7 & 93,1 & 5,2 & 0,2 \\
\hline Prispevki v kongresnih zbornikih (1.06-1.13) & 8,4 & 70,2 & 4,3 & 1,8 \\
\hline Poglavja v monografijah (1.16-1.17) & 8,0 & 70,3 & 5,6 & 1,5 \\
\hline Drugi prispevki v serijskih publikacijah (1.19-1.25) & 4,9 & 75,4 & 3,6 & 0,4 \\
\hline Poročila, elaborati ipd. (2.12-2.15) & 5,6 & 76,2 & 3,6 & 0,7 \\
\hline Zaključna dela (2.08-2.11) & 6,1 & 98,9 & 5,8 & 0,2 \\
\hline Kongresni zborniki (2.3* in 2.25) & 8,9 & 82,1 & 5,3 & 3,0 \\
\hline Druge monografije (2.01-2.07, 2.16-2.24) & 6,7 & 65,6 & 4,8 & 0,8 \\
\hline Neobjavljena dela (3*) & 7,2 & 58,5 & 4,0 & 0,5 \\
\hline Povprečje & $\mathbf{6 , 6}$ & $\mathbf{7 8 , 3}$ & $\mathbf{4 , 5}$ & $\mathbf{0 , 8}$ \\
\hline
\end{tabular}

Na področju klasifikacije UDK je slika precej drugačna. Če so ključne besede povprečno v $24,9 \%$ navedene na viru in jih v povprečju $26,2 \%$ določi avtor ob oddaji dela za vnos v osebno bibliografijo (tabela 2), je UDK $v$ virih ( $k$ g ga primarno vnašamo $v$ podpolje $675 a$ ) naveden le $v$ 4,2 \%. Večino predstavljajo zaključna dela, nekaj je tudi (domačih) znanstvenih člankov. Tako v kar 95,8 \% ta naloga pripada knjižničarju bibliografu ali drugemu knjižničarju, zadolženemu za določanje klasifikacijskih oznak.

\subsection{Vključevanje podatka o afiliaciji v bibliografski zapis}

Glede na odgovore knjižničarjev bibliografov $(n=113)$ v anketnem vprašalniku podatek o afiliaciji (podpolje 70X8), ki je pogoj za izdelavo bibliografije ustanove, redno vnaša le $1 \%$ sodelujočih pri anketiranju, nikoli $16 \%, 55 \%$ vprašanih samo za raziskovalce matične organizacije, $28 \%$ sodelujočih pa, če je podatek naveden na publikaciji ali če raziskovalce pozna.

Na primeru sedemdesetih knjižnic je prikazano stanje o: 
- številu izpolnjenih podpolj 70X8 pri vsaj enem izmed avtorjev dela, in sicer za dela, nastala v obdobju 2010-2015, kot je zavedeno v COBIB.SI, in

- številu del, vključenih v bibliografijo RO glede na vključene raziskovalce (tabela 4).

Tabela 4: Primerjava izpisa bibliografij RO iz COBISS3 in SICRIS (obdobje 2010-2015)

\begin{tabular}{llll}
\hline Stanje v izpisu & $\begin{array}{l}\text { Visokošolska } \\
\text { knjižnica }\end{array}$ & $\begin{array}{l}\text { Specialna } \\
\text { knjižnica }\end{array}$ & Skupaj \\
\hline Število zajetih knjižnic & 44 & 26 & $\mathbf{7 0}$ \\
\hline $\begin{array}{l}\text { Število zapisov z izpolnjenim podpoljem 70X8 } \\
\text { (COBIB.SI) }\end{array}$ & 214.659 & 84.167 & $\mathbf{2 9 8 . 8 2 6}$ \\
\hline $\begin{array}{l}\text { Število zapisov v izpisih 'Vrednotenje bibliografskih } \\
\text { kazalcev raziskovalne uspešnosti po metodologiji } \\
\text { ARRS' }\end{array}$ & 268.286 & 101.825 & $\mathbf{3 7 0 . 1 1 1}$ \\
\hline
\end{tabular}

Izpis iz vmesnika COBISS3 na podlagi izpolnjenega podpolja 70X8 prikaže okoli $20 \%$ manj enot kot izpis iz sistema SICRIS (bibliografija RO).

\section{Razprava in zaključki}

V prispevku spremljamo doslednost pri vnosu predmetnih oznak predvsem zaradi potrebe po najdbi gradiva $v$ katalogu COBIB.SI tako za domače kot za tuje govoreče uporabnike. Menimo, da so predmetne oznake $v$ tujem (predvsem angleškem) jeziku dodana vrednost zapisu tudi zaradi vse večjih izmenjav podatkov med COBISS.SI ter vzpostavljenim Nacionalnim portalom odprte znanosti in drugimi zbirkami.

Rezultati raziskave so pokazali, da večina (84 \%) knjižničarjev bibliografov, ki so odgovorili na naš vprašalnik, v zapise, namenjene za vodenje bibliografij, vnaša predmetne oznake $v$ slovenskem jeziku in tako prispeva $\mathrm{k}$ boljši najdljivosti in kakovosti zapisov $\mathrm{v}$ slovenskem vzajemnem katalogu. Okoli $15 \%$ vprašanih običajno ne izvede vsebinske analize vira, razen če so ključne besede navedene $v$ delu ali jih je posredoval avtor. Zapisi iz COBIB.SI se prenašajo $v$ tuje kataloge in e-repozitorije, kar slovenski znanosti ponuja preprosto priložnost za promocijo. S tega vidika nas lahko skrbi tudi dejstvo, da $13 \%$ vprašanih knjižničarjev bibliografov $v$ zapise nikoli ne vključuje predmetnih oznak $v$ angleškem jeziku. Čeprav vnos predmetnih oznak ni obvezen, le priporočljiv, lahko zaključimo, da se ta delež knjižničarjev bibliografov ne zaveda pomena tega podatka. Veljalo bi jih opozoriti, da so ti zapisi predmet mnogih izmenjav in je zato vse zapise, tudi zapise za gradivo $v$ slovenščini, treba opremiti tudi s predmetnimi oznakami v angleščini. Zavedamo se, da so knjižničarji bibliografi mnogokrat podvrženi časovnemu pritisku, saj se od njih zahteva takojšen vnos dela. Poleg tega so obremenjeni še z drugim delom in se, tudi zavestno, odpovedujejo podrobni vsebinski obdelavi.

Raziskovali smo možnosti izpisa bibliografij ustanov v sistemu COBISS. Iz kataloga COBIB.SI je to možno, če je dosledno izpolnjeno podpolje 70X8 (afiliacija avtorja), kar je obvezen podatek za zapise, ki jih določena ustanova želi uvrstiti v bibliografijo ustanove. Ugotavljamo, da tega podatka $16 \%$ anketirancev nikoli ne vnaša, $28 \%$ pa le, če je podatek naveden na viru. Rezultati naše raziskave kažejo na nedoslednost pri vnašanju tega podatka, zato se sprašujemo, ali se slovenske RO zavedajo pomena promocije lastnih dosežkov prek letnih in priložnostnih 
bibliografij. Kvaliteta izpisa je tesno povezana s kvalitetnim delom knjižničarja bibliografa. Da bi zagotovil popolnost bibliografije organizacije, bi knjižničar bibliograf moral tudi redno spremljati zapise za dela raziskovalcev svoje ustanove, ki so jih kreirali drugi katalogizatorji, in jih dopolniti s podatkom o afiliaciji.

Prek sistema SICRIS ni možno pripraviti izpisa bibliografije RO (ki bi vključil dela raziskovalcev, povezanih z organizacijo $v$ izbranem obdobju, $v$ času priprave izpisa pa več ne, in hkrati le tista dela izbranih raziskovalcev, ki so jih ti objavili v sklopu dela v tej organizaciji, ne pa v okviru vzporednega dela drugje). Možnost, ki jo običajno uporabljamo, je vrednotenje raziskovalne uspešnosti določene organizacije ali skupine, a to ni prava retrospektivna bibliografija organizacije. Algoritem v izpis vključi le dela raziskovalcev, ki so trenutno člani raziskovalne skupine ali ustanove, in sicer ne glede na to, ali so dela nastala $v$ sklopu njihovega dela $v$ tej ali kakšni drugi organizaciji. Poleg tega ne vključi z zamikom objavljenih del raziskovalcev, ki so v organizaciji delovali v preteklosti ali le del obdobja.

\section{Zahvala}

Avtorja se želiva zahvaliti vsem knjižničarjem, ki so izpolnili anketo. Pri oblikovanju anketnega vprašalnika so sodelovali člani izvršnega odbora Sekcije za visokošolske knjižnice pri ZBDS. Poudariti želiva pomoč Nataše Knap (Narodna in univerzitetna knjižnica) in Leje Borovnjak (Teološka fakulteta Univerze $v$ Ljubljani) $v$ fazi priprave in promocije ankete ter Kristine Pritekelj (Filozofska fakulteta Univerze v Ljubljani), ki je opravila lektorski pregled. Pri pripravi vprašalnika je koristne napotke posredovala tudi dr. Ema Dornik (IZUM). Za koristne napotke se zahvaljujeva tudi recenzentom.

\section{Reference}

Badovinac, B., 2018. Nabor dimenzij za opredelitev kakovosti podatkov $v$ bibliografskih in normativnih zapisih. Organizacija znanja, 23(1/2), 2-10.

Badovinac, B., 2019. „Pikice in vejice« pod drobnogledom: spremljanje kakovosti zapisov v letu 2018. Blog COBISS, 27. 5. 2019. Dostopno na: https://blog.cobiss.si/2019/05/27/pikicein-vejice-pod-drobnogledom/ [29. 1. 2020].

BibSiST online: statistični podatki o knjižnicah, 2018. Ljubljana: Narodna in univerzitetna knjižnica, Center za razvoj knjižnic. Dostopno na: http://bibsist.nuk.unilj.si/statistika/index.php [8. 10. 2018].

COMARC/B format: za bibliografske podatke, 2019. Maribor, IZUM. Dostopno na: https://izobrazevanje.izum.si/EntryFormDesktopDefault.aspx?tabid=38\&type=manual\&man ual=1 Comarc B svn [20.1. 2020].

Dornik, E., Badovinac, B., Kos, J. in Farkaš, B., 2017. Sistem zagotavljanja kakovosti COBIB.SI: izbrane aktivnosti za leto 2016. Knjižnica, 61(1-2), str. 191-205.

Dornik, E., 2019. Zagotavljanje kakovosti COBIB.SI: kako uspešni smo? V: Knjižnice obvladovalke podatkov? Kongres Zveze bibliotekarskih društev Slovenije, Maribor, 25.-27. september 2019. Ljubljana: Zveza bibliotekarskih društev Slovenije. Str. 35-50. 
Dovoljenja za vzajemno katalogizacijo, 2018. Maribor: IZUM. Dostopno na: http://izobrazevanje.izum.si/EntryFormDesktopDefault.aspx?tabid=360\&type=licence [8. 10. 2018].

Galeffi, A., Bertolini, M.V., Bothmann, R.L., Escolano Rodríguez, E. in McGarry, D., 2019. Izjava o mednarodnih katalogizacijskih načelih (ICP). Ljubljana: Narodna in univerzitetna knjižnica. Dostopno na: https://www.nuk.unilj.si/sites/default/files/dokumenti/2019/ICP 2017.pdf [20. 1. 2020].

Južnič, P., 2015. Pomen urejenih bibliografij za spremljanje in vrednotenje znanstvenoraziskovalnega dela. Organizacija znanja, 20(1), str. 10-14.

Klemen, A., 2011. Ustreznost vsebinskih opisov dokumentov $v$ online dostopnem knjižničnem katalogu. Knjižnica, 56(1/2), str. 55-75.

Koler-Povh, T., 2016. Vloga knjižničarja pri izgradnji institucionalnega repozitorija: izziv ali nuja? V: Upravljanje znanja v knjižnicah: posvetovanje sekcij ZBDS, Maribor, 2016. Dostopno na: http://www.zbds-zveza.si/sites/default/files/dokumenti/2013/izvlecek koler2016.pdf [8. 10. 2018].

Likar, T., 2003. Enotna obdelava knjižničnega gradiva - pogoj za izmenjavo in skupno uporabo bibliografskih zapisov. Knjižnica, 47(1/2), str. 7-34.

Logar, J., 1970. Uvod v bibliografijo. Ljubljana: Narodna in univerzitetna knjižnica.

Mišković, V., 2010. Na začetku je (bila) knjiga: bibliografija na Slovenskem. Ljubljana: Narodna in univerzitetna knjižnica.

Peteh, M. in Južnič, P., 2018. Vrednotenje bibliografske storitve v luči raziskovalne dejavnosti: pomen in vpliv vodenja bibliografije raziskovalcev za knjižničarje v slovenskih raziskovalnih knjižnicah. Knjižnica, 63(1), str. 117-137.

Škerget, D. in Rifl, B., 2014. Spletni viri in slovenska bibliografija: študija primera. Knjižnica, 58(1/2), str. 35-56.

Zapisnik sestanka s predstavniki OSIC-ev in ARRS-ja [z dne 15. 11. 2018], 2018. Maribor, IZUM. Dostopno na: https://www.cobiss.si/zapisniki/delovne-skupine/Zapisnik Sestanek z OSICi in\%20ARRS 2018-11-15.pdf [20. 2. 2018]. 